\title{
THE INFLUENCE OF THE FUNDAMENTAL FACTORS ON PLANTATION COMPANIES' FIRM VALUE ON THE INDONESIA STOCK EXCHANGE
}

\author{
Siska Gita Pratiwi ${ }^{1}$, Robiyanto Robiyanto ${ }^{2 *}$, Harijono Harijono ${ }^{3}$ \\ ${ }^{1,2,3}$ Faculty of Economics and Business, Universitas Kristen Satya Wacana, Salatiga, Indonesia \\ e-mails: ${ }^{1} 212017216 @$ student.uksw.edu; ${ }^{2}$ robiyanto.robiyanto@uksw.edu; ${ }^{3}$ harijono.harijono@uksw.edu
}

Received November 13, 2020; accepted January 19, 202; published January 29, 2021.

\begin{abstract}
Objective: Indonesia's economic growth is mostly supported by the agricultural sector in which the plantation sub-sector has a significant contribution to the primary sector in the sectoral index of Indonesia Stock Exchange (IDX). Plantation companies have a long-term goal of maximizing shareholder prosperity by increasing company values. This study aimed to determine the influence of fundamental factors on company values of plantation companies listed on the IDX during 2015-2019. Research Design \& Methods: This study used secondary data involving 8 samples of plantation companies listed on the IDX using a purposive sampling method and panel regression analysis techniques. Research data was taken from the annual reports on the IDX. Findings: The results showed that Managerial Ownership (MO), Debt to Equity Ratio (DER), Earnings per Share (EPS), and Company Age (AGE) have a positive correlation to Firm Value (FV). However, the probability of MO, EPS, AGE is not significant and only DER has a significant effect on FV. Recommendations: There is a blemish in research for further research that is expanding the scope of research, and future studies is suggested to analyze the fundamental influence on FV before and during the Covid-19 period. This cannot be done in this study because the data is still limited. Contribution \& Value Added: This result contributes to the financial literature and can be a consideration for investors in investment based on company value.
\end{abstract}

Keywords: firm value; fundamentals; panel regression; Indonesia Stock Exchange.

JEL codes: G32, G39

Article type: research paper

\section{INTRODUCTION}

Indonesia's economic growth mostly supported by the agricultural sector, which is one of the primary sectors in the sectoral index of the IDX and dominated by plantation companies. At this country, plantation production has increased in the last five years from 2015 to 2019 which can be seen in Figure 1, most of the increase comes from palm oil production. Therefore, Indonesia becomes one of the main palm oil producers and has good prospects for the plantation industry.

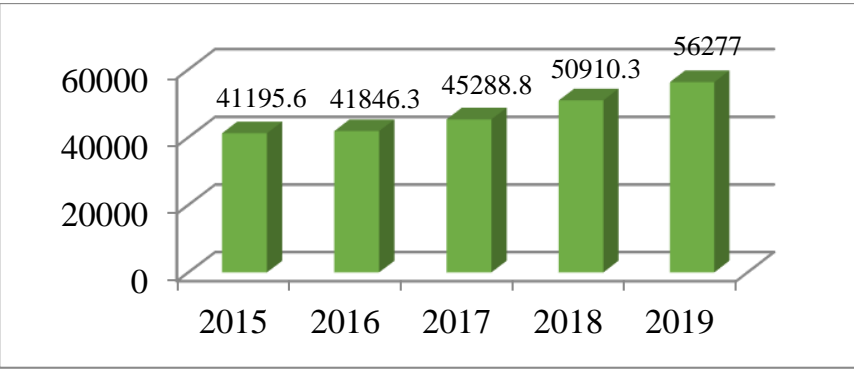

Figure 1. Growth of Plantation Crop Production (in Tonnes)

Source : bps.go.id 
Year of 2019 was a tough year for the palm oil industry due to uncontrolled prices and depended on supply and demand. The decline in Crude Palm Oil (CPO) prices occurred due to excess supply from major producers, namely Malaysia and Indonesia, and the trade war between China and the United States. Despite the decline in CPO prices, the national productivity of the palm oil industry still grew in 2019 reaching 51.8 million tons (gapki.id). Indonesian President also requested reducing the CPO exports because the government will implement B30 that predicted to increase demand for CPO in Indonesia by 5-6 million tons. If the implementation of $\mathrm{B} 30$ runs properly, the share price of plantation companies will increase (CNBC, 2020).

Oil palm plantation companies in Indonesia also provide the highest contribution with the most trade transactions in plantation sub-sector. Good company performance can increase firm value (FV) through stock price stability and increase in the long-term. The higher the share price, the higher the FV (Haryati \& Ayem, 2014). Investors tend to be interested in maximum FV because they can provide maximum prosperity for shareholders when share price increase (Untu \& Welley, 2015). FV is influenced by internal factors in the form of fundamental analysis that can increase or decreases FV including Managerial Ownership (MO), Debt to Equity Ratio (DER), and Earning Per Share (EPS) (Choi et al., 2012).

Warapsari \& Suaryana (2016) argue that the greater MO with better management performance will increase FV as company activities are directly monitored through managerial ownership. This follows the agency theory by Jensen \& Meckling (1976) where companies need to have a good and not opportunistic management so that there is no conflict of interest between managerial and shareholders. This is consistent with research by Abbas et al. (2013); Rachman \& Maghviroh (2012) which stated that FV is positively influenced by MO. Different from the research of Rustan et al. (2014); Sujoko \& Soebiantoro (2017) argue that MO does not affect FV.

The debt ratio that measures a company's equity to its liabilities is DER. When DER decreases, FV will increase. Trade-off theory explains that the use of debt that exceeds the optimal limit will result in bankruptcy costs and reduce firm value (Myers, 1977). Previous research by Dewi \& Wirajaya (2013); Hidayati (2010) argues that DER negatively affects FV. However, Putri et al. (2018); Suteja \& Manihuruk (2009); Wicaksana et al. (2016) explained that DER has positively affected FV.

The company's ability to obtain shareholders benefits is important in measuring FV, it can be seen through EPS. Companies must be able to influence share prices in the capital market in order to increase FV by increasing the value of traded stock (Subing \& Susiani, 2019). Kholis, Sumarmawati, \& Mutmainah (2018); Kusuma \& Priantinah (2012) explained that EPS has an effect on FV, the higher the EPS, the higher the FV. However, the results from Pioh et al., (2018); Wicaksana et al. (2016) states that EPS does not affect FV.

Another factor affecting FV is the age of the company (AGE). Companies that remain consistent even though they are old are said to have good performance and high FV. This is consistent with Driffield, Mahambare, \& Pal (2007) stated that FV is positively influenced by company age. However, this contradicts by Choi et al. (2012) stated that AGE negatively affect FV.

Previous studies have shown inconsistent results due to differences in the sectors studied, different timeframes and analysis techniques that mostly use multiple regression which is considered inaccurate for analyze the combined data. The results of previous studies have also not been able to provide consistent results based on the theory used as the research foundation. Therefore, this research used panel regression because more suitable for analyzing combined cross-section and time-series data, the object was plantation companies with a research period from 2015-2019, where plantation companies are still rarely researched and continue to experience increased production in that year and is the subsector of the agricultural sector that has the biggest contribution in trade.

Based on the phenomena and gaps in previous studies, researchers are interested in knowing the influence of fundamental factors on firm value with case studies on the plantation industry listed on the IDX for the period 2015 to 2019. This research is expected to be a consideration for investors before making investment decisions to minimize the risks that will occur. For the company, it is 
expected to be used as material for evaluating, optimizing and increasing FV. Besides, this current research is also expected to add to the literature in the education sector.

\section{LITERATURE REVIEW}

\section{Agency Theory}

Agency theory according to Jensen \& Meckling (1976) is a relationship between agents (company management) and principals (shareholders) which may cause conflicts. Agency issues occur because of supervision in the firm and separation of ownership resulting in asymmetric information. It happens when management appointed to manage the company perform opportunistic actions to increase personal interests without approval. Increasing MO can minimize opportunistic actions as it can align interests of management and shareholders so that managers will act in line with shareholder's needs.

\section{Trade-Off Theory}

The Trade-Off theory explains that there is optimal leverage (debt ratio) on the capital structure and FV (Myers, 1977). The use of debt will increase firm values to certain leverage (optimal) and after exceeding it can lead to greater bankruptcy costs and result in a decrease in FV. The trade-off theory also reveals that the amount of debt that exceeds the optimal point can cause financial distress and the decrease of the FV so that the company cannot pay its debt (Warapsari \& Suaryana, 2016).

\section{Signalling Theory}

According to Suteja \& Manihuruk (2009), signalling theory explains the conditions that management and directors have better information about the company's current and future than investors. An example of conveying information through signalling is the payment of dividends. Investors will consider the firm's current and future finances (earnings prospects) are relatively good if management notifies an increase in the amount of dividends per share distributed. Then, the manager is considered send a negative signal if does not distribute dividends.

\section{Firm Values}

Firm values (FV) describes condition that the company has achieved as public trust in the firm from its establishment until now (Rinnaya et al., 2016). FV will generate future profits which is described by the stock price (Kholis et al., 2018). Dewi \& Wirajaya (2013) explains that FV is the price that must be paid by investors when buying a company, usually associated with stock price and has crucial roles for investors. If the stock price rises, FV will increase. FV can be described from company management as good or bad management will affect the FV (Noviani et al., 2019).

\section{The Effect of Managerial Ownership on Firm Values}

A condition where managers own company shares is called managerial ownership (MO) (Christiawan \& Tarigan, 2007). It is indicated by the percentage of the company's share ownership by the manager in the annual report. Agency theory explains that management and shareholders' interests may cause conflicts. The presence of MO can reduce conflict. Therefore, increasing managerial ownership can connect the interests of internal parties and shareholders which expected to increase FV. Past research by Abbas et al. (2013) stated that an increase in MO provides positive effects on the FV. This is similar to the research of Rizqia et al. (2013) that MO has significant positive effects on the FV, the higher the proportion of MO, the higher the FV.

H1: Managerial ownership has a positive effect on firm value.

\section{The Effect of Debt to Equity Ratio on Firm Values}

Capital structure is crucial in company funding decisions. The capital structure theory explains that a company can balance costs arising from debt with benefits, there will be no problems then the capital structure can increase company profits and welfare through the increase in FV (Noviani et al., 2019). The debt to equity ratio (DER) is the debt ratios that is predicted to affect FV. The higher the DER, the 
lower the FV and vice versa. It is same as previously conducted by Dewi \& Wirajaya (2013); Noviani et al. (2019); Subing \& Susiani (2019) which found that DER has a negative effect on FV meaning that an increase in debt will be followed by a decrease in the FV.

H2: DER has a negative effect on firm values.

\section{The Effect of Earnings per Share on Firm Values}

Earnings per Share (EPS) is a ratio that needs to be considered by investors because it describes the company's prospects (Husaini, 2018). EPS is the net income that can be achieved by company from each share when running its operations (Haryati \& Ayem, 2014). Meanwhile, Syamsuddin (2007) stated that company management, common stockholders, and potential investors are interested in EPS because it shows the amount of money to be earned for each common share.

The company's goal is to maximize profits. Therefore, any policies related to maximizing share prices are always related the company's ability to improve shareholder's prosperity (Kusuma \& Priantinah, 2012). A study by Kholis et al. (2018) found that EPS has a positive effect on FV meaning that if EPS increases, the FV will also increase.

H3: EPS has a positive effect on firm values.

\section{The Effect of Company Age on Firm Values}

Company age (AGE) is the length of the establishment years of a company. Companies that have been established longer will have more experience and good performance and reputation enabling the firm to have high-profit margins when selling their products (Arisadi et al., 2013). According to Lee \& Choi (2015), the older AGE, the closer the relationships with FV. It allows the company to have better long-term investment decisions that affect the FV. Studies by Dahya et al. (2008); Driffield et al. (2007); Yumiasih \& Isbanah (2017) argue that AGE has a positive effect on FV. It means that the older the company age, the higher the FV.

H4: Company age has a positive effect on firm values.

\section{METHODS}

\section{Type and Data Source}

This study used panel data, which is a combination of time series and cross-section, sourced comes from secondary data in the form of annual reports on idx.co.id which contains data on the variables managerial ownership (MO), Debt to Equity Ratio (DER), Earning per Share (EPS), Company Age (AGE), and firm value (TOBIN'S Q).

\section{Population and Sample}

The population of this research was all plantation companies listed on the IDX in 2015-2019. The sampling method used was purposive sampling. The sample selection process is based on the following criteria:

Table 1. Sample Selection Process Based on Criteria

\begin{tabular}{ccc}
\hline Number & Criteria & Amount of the Company \\
\hline 1 & All plantation companies on the IDX 2015-2019 & 18 \\
2 & Plantation companies that have incomplete financial reports & $(4)$ \\
3 & Companies with extreme values & $(6)$ \\
\hline Final sample amount & 8 \\
Observation year & 5 \\
Amount of observations & 40 \\
\hline
\end{tabular}

The list of stocks as shown in Table 2 below. 
Table 2. List of Sample Plantation Companies on the IDX 2015-2019

\begin{tabular}{cll}
\hline Number & \multicolumn{1}{c}{ Code } & \multicolumn{1}{c}{ Name of Company } \\
\hline 1 & ANJT & Austindo Nusantara Jaya Tbk. \\
2 & DSNG & Dharma Satya Nusantara Tbk. \\
3 & LSIP & PP London Sumatra Indonesia Tbk. \\
4 & MAGP & Multi Agro Gemilang Plantation Tbk. \\
5 & PALM & Provident Agro Tbk. \\
6 & SGRO & Sampoerna Agro Tbk. \\
7 & SIMP & Salim Ivomas Pratama Tbk. \\
8 & TBLA & Tunas Baru Lampung Tbk. \\
\hline
\end{tabular}

Source: www.idx.co.id

\section{Operational Variable}

To find out the fundamental factors on firm value, this study used the following variables:

Table 3. Operational Variable

\begin{tabular}{|c|c|c|}
\hline Variable & Formula & Source \\
\hline \multicolumn{3}{|l|}{ INDEPENDENT } \\
\hline \multirow[t]{2}{*}{ Managerial Ownership } & Number of Managerial Shares & Rizqia et al. (2013) \\
\hline & $\overline{\text { Number of Shares Outstanding }}$ & \\
\hline \multirow[t]{2}{*}{ Debt to Equity Ratio } & Total Liabilities & Sari \& Hutagaol (2009) \\
\hline & Total Equity & \\
\hline \multirow[t]{2}{*}{ Earning Per Share } & Net Profit & Widyastuti \& Andamari \\
\hline & $\overline{\text { Number of Shares Outstanding }}$ & $(2013)$ \\
\hline \multirow[t]{2}{*}{ Company Age } & Age $=$ Year $\mathrm{t}-$ Year $\mathrm{n}$ & Subing \& Susiani (2019) \\
\hline & $\begin{array}{c}\text { *Year } \mathrm{t}=\text { year annual report under study } \\
\text { Year } \mathrm{n}=\text { year company standing }\end{array}$ & \\
\hline \multicolumn{3}{|l|}{ DEPENDENT } \\
\hline \multirow[t]{2}{*}{ Firm Value (TOBINS'Q) } & Market Value of Equity + Total Debt & Subing \& Susiani (2019) \\
\hline & Total Asset & \\
\hline
\end{tabular}

\section{Data Analysis Technique}

The panel regression was used to test the effect of independent variables, which are MO, DER, EPS, and AGE on the dependent variable, namely firm value (FV) using the EVIEWS test tool. The model determination test was used to determine the best panel regression method between Fixed Effect Model (FEM), Random Effect Model (REM), and Common Effect Model (CEM) through the Chow test, Hausman test, and Lagrange Multiplier test. The panel regression equation model is as follows:

$$
Y_{i t}=a+\beta 1 X 1_{i t}+\beta 2 X 2_{i t}+\beta 3 E X 3_{i t}+\beta 4 X 4_{i t}+e_{i t}
$$

Information:

$$
\begin{array}{ll}
Y_{i t} & : \text { Firm Value i company, year } \mathrm{t} \\
a & : \text { Constant } \\
\beta & : \text { Regression Coefficient } \\
X 1_{i t} & : \text { MO i company, year } \mathrm{t} \\
X 2_{i t} & : \text { DER i company, year } \mathrm{t} \\
X 3_{i t} & : \text { EPS i company, year } \mathrm{t} \\
X 4_{i t} & : \text { AGE i company, year } \mathrm{t} \\
e_{i t} & : \text { Error i company, year } \mathrm{t}
\end{array}
$$




\section{FINDING}

\section{Descriptive Statistics}

Descriptive statistical analysis consists of mean, standard deviation, minimum, and maximum can be seen in Table 4.

Table 4. Descriptive Statistics

\begin{tabular}{cccccc}
\hline Variable & Obs & Mean & Std. dev & Min & Max \\
\hline FV & 40 & 0.99 & 0.25 & 0.38 & 1.51 \\
MO & 40 & 2.62 & 4.34 & 0.00 & 10.87 \\
DER & 40 & 1.08 & 0.77 & 0.13 & 2.68 \\
EPS & 40 & 52.86 & 65.32 & -35.00 & 233.8 \\
AGE & 40 & 32.00 & 14.52 & 14.00 & 58.00 \\
\hline
\end{tabular}

Source: processed data

The results in Table 4 show that the average FV was 0.99 with a minimum value of 0.38 by ANJT in 2019 and a maximum value of 1.51 by DSNG in 2015. A high FV indicates that the company can increase the prosperity of the shareowners because it is followed by an increase in share prices.

MO has an average of $2.62 \%$ with a minimum value of $0.00 \%$ namely LSIP, MAGP, and SGRO. Meanwhile, the maximum value was at DSNG in 2019 is $10.87 \%$. The higher the MO, the higher the $\mathrm{FV}$ along with the increasing shareholder welfare.

The average capital structure with DER was 1.08 times. The minimum value was 0.13 times by PALM in 2019, while the maximum value was 2.68 times by TBLA in 2016. A high DER illustrates that the company's debt is greater than the company's capital so that the FV will decrease because companies that have too much debt to exceed the optimal limit will experience bankruptcy costs.

Mean of EPS was 52.86 with a minimum value of -35.00 by SIMP in 2019 and a maximum was 233.8 by SGRO in 2016. High EPS indicates high FV because the income received by shareholders also increases, so as to increase the welfare of shareholders.

AGE has a mean of 32 years with a minimum value of 14 years by PALM and a maximum was 58 years by LSIP. The higher the AGE is considered to have good company performance and value because the company is considered capable of making better investment decisions in the long term.

\section{Classic Assumption Test}

The classical assumption test carried out was to test for normality, heteroscedasticity, and multicollinearity which can be seen in Table 5 .

Table 5. Classic Assumption Test

\begin{tabular}{lcc}
\hline \multirow{2}{*}{ Normality Test } & Jarque-Bera & Prob \\
& 0.12 & 0.94 \\
\hline \multirow{2}{*}{ Heteroscedasticity Test } & Obs*R-Squared & Prob. Chi-Square \\
& 3.79 & 0.44 \\
\hline \multirow{2}{*}{ Multicollinearity Test } & Variable & VIF \\
& MO & 1.01 \\
& DER & 1.08 \\
& EPS & 1.33 \\
\hline
\end{tabular}

Source: Processed data

Normality test is used to see the distribution of data is normal or not. According to the results of normality testing using the Jarque-Bera test, it showed the probability was 0.94 exceeding 0.05 so the data was normal and fulfils the requirements of the normality test. The heteroscedasticity test produces a Chi-Square Probability of 0.44 that was bigger than 0.05 , meaning that there was no heteroscedasticity or it fulfils the assumption that the data is proven to be homoscedasticity. The multicollinearity test show that there was no multicollinearity problem between the independent 
variables because the Variance Inflation Factors (VIF) of all independent variables was smaller than the critical value (VIF <10) so, it was said to pass the multicollinearity test.

\section{Determination of Regression Model}

To determine the appropriate regression model, testing was carried out using the Chow test and the Lagrange Multiplier (LM) test as can be seen in Table 6.

Table 6. Result of the Regression Model Determination Test

\begin{tabular}{lcc}
\hline Chow Test & Statistic & Prob \\
& 6.97 & 0.14 \\
\hline Lagrange Multiplier Test & Cross-section & Prob. \\
(Breusch-Pagan) & 8.219 & 0.004 \\
\hline
\end{tabular}

Source: Processed data

Chow test is done to determine the estimate between Common Effect Model (CEM) and Fixed Effect Model (FEM) by looking at the Chi-Square probability value. Because the Chow test results was 0.14 that was more than 5\%, the determination of the best model estimation was used CEM. Then proceed with the LM test and the probability was 0.004 smaller than 5\% so the best estimation model was to use the Random Effect Model.

\section{Panel Regression Analysis Results}

Based on the model determination test, the Random Effect Model was chosen as the most appropriate model for conducting panel regression tests in research.

Table 7. The Estimation Results of Random Effect Model

\begin{tabular}{ccc}
\hline Variable & Coefficient & Prob. \\
\hline C & 0.641 & 0.004 \\
MO & 0.010 & 0.600 \\
DER & 0.136 & 0.035 \\
EPS & 0.001 & 0.131 \\
AGE & 0.004 & 0.509 \\
\hline R-squared & & 0.216 \\
Adjusted R-squared & & 0.126
\end{tabular}

Source: Processed data

The panel regression equation based on the results of the analysis in Table 7 was as follows:

$$
Y_{i t}=0.641+0.010 X 1_{i t}+0.136 X 2_{i t}+0.001 X 3_{i t}+0.004 X 4_{i t}+\left(\mu_{i}+v_{i t}\right)
$$

Information:

$$
\begin{array}{ll}
Y_{i t} & : \text { Firm Value i company, year } \mathrm{t} \\
a & : \text { Constant } \\
\beta & : \text { Regression Coefficient } \\
X 1_{i t} & : \text { MO i company, year } \mathrm{t} \\
X 2_{i t} & : \text { DER i company, year } \mathrm{t} \\
X 3_{i t} & : \text { EPS i company, year } \mathrm{t} \\
X 4_{i t} & : \text { AGE i company, year } \mathrm{t} \\
e_{i t} & : \text { Error } \text { i company, year } \mathrm{t} \\
\mu_{i}+v_{i t} & \text { Random Effect }
\end{array}
$$

The results of the regression coefficients in Table 7 show that all research variables have a positive coefficient value, meaning that when the independent variable increases by one unit, the FV also increase the same as the regression coefficient. The result of probability of MO is 0.600 greater than $5 \%$, meaning that when there was a change in the rise or fall of $\mathrm{MO}$, it will not affect the change in FV. DER has a significant positive effect on FV seen in the coefficient results of 0.136 and the probability of 0.035 is smaller than alpha 5\%. When DER increase, FV also increase, and vice versa. 
EPS has a probability result of 0.131 and the results of probability of AGE was 0.509 so that both are proven to not affected FV, the increase or decrease in EPS and AGE did not affect FV. The next test result showed Adjusted R-squared value of 0.126 , this explained that $12.6 \%$ of the FV variable was represented by the variables MO, DER, EPS, AGE and the rest are other factors outside the model.

\section{DISCUSSION}

\section{The Effect of Managerial Ownership on Firm Values}

This study found that the first hypothesis, 'MO has a positive effect on FV' was rejected. The results show that MO has no effect on FV with a probability of 0.600 higher than $5 \%$. Supported by Rustan et al. (2014); Sujoko \& Soebiantoro (2017) which found that MO did not effect on FV. This finding was inconsistent with agency theory which states that the proportion of $\mathrm{MO}$ can reduce conflicts of interest (Jensen \& Meckling, 1976). The theory that was following the results of this study was the stewardship theory which explains if managers are not motivated by individual goals but aimed at organizational interests, so the level of $\mathrm{MO}$ does not affect management behavior in increasing FV (Madison, 2014). Besides, it was also caused by a low MO in the research sample in the company so that it did not have a significant influence on FV.

\section{The Effect of Debt to Equity Ratio on Firm Values}

The second hypothesis is that DER negatively affects FV. Based on the panel regression test, the probability of DER was 0.035 smaller than $5 \%$ and the coefficient was 0.136 so, Ho was accepted. This research showed that DER has a significant positive effect on FV, the higher the DER the higher the FV and vice versa. It was similar with studied by Putri et al. (2018); Wicaksana et al. (2016) which found that DER has a positive effect on FV. This can happen because some investors think that if the company dares to have high debt, then the company is assumed to be able to pay off its debt. Company debt is also considered capable of increasing FV because it can save on tax expenses (Rahmantio et al., 2018). However, this needs to be done with good company management and maintaining debt stability so as not to exceed the optimal limit because it can cause bankruptcy costs and can actually reduce FV.

\section{The Effect of Earnings per Share on Firm Values}

The third hypothesis in this study is that EPS has a positive effect on FV. The test showed a probability is 0.131 higher than $5 \%$ meaning that $\mathrm{H}_{3}$ is rejected. It is same with the findings of Lilianti (2013); Pioh et al. (2018); Fachrudin (2014); Wicaksana et al. (2016) argue that EPS does not affect the FV. It indicates that an increase or decrease in EPS will not affect the FV. This can happen because the firm does not provide the benefits obtained by shareholders in the form of dividends, in addition to capital gains, investors also expect returns in the form of dividends. Companies that do not pay dividends can occur if the firm is experiencing financial difficulties or withholding dividends to be used as funding for large investments (Maulana, 2014). Investors prefer if the company pays dividends on time rather than postpone it, so is not following the signal theory stated that investors will catch a positive signal if the firm makes payments on time because in this theory the company have better information than investors. Therefore, high EPS does not necessarily provide the desired return so it cannot be used to predict stock prices as a determinant of FV.

\section{The Effect of Company Age on Firm Values}

The fourth hypothesis is that AGE has a positive effect on FV. The test showed that AGE has a probability of 0.509 more than $5 \%$ meaning that $\mathrm{H}_{4}$ was rejected. It was same with research by Choi et al. (2012); Halim \& Christiawan (2019) which found that company age does not have a positive effect on the FV. It explains that the older the company is not always followed by higher FV. This condition can occur if a company that has been established for a long time is unable to keep up with technological developments and market developments, it will lose to a new company that can adapt to the current era of globalization. So that the FV cannot be seen from the AGE, because now many startup companies can develop rapidly even though their age is only a short time. 


\section{CONCLUSION}

This study aimed to analyze the fundamental factors that affect FV in plantation companies on the Indonesia Stock Exchange (IDX) for the 2015-2019. The fundamental factors used are Managerial Ownership (MO), Debt to Equity Ratio (DER), Earnings per Share (EPS), and Company Age (AGE) with the dependent variable to measure Firm Value (FV) using TOBIN'S Q. Based on the research that has been done using panel regression techniques, it is concluded that MO, DER, EPS, and AGE have a positive relationship to FV seen from the coefficient values which all show positive values. When MO, DER, EPS, and AGE increase, FV will also increase, and vice versa. However, the probability of the MO, EPS, and AGE is not significant and only DER has a significant effect on FV.

Companies can pay attention to the fundamental factors that affect the FV, by doing the right analysis, the company's performance will increase and can also increase the FV because investors are more interested in investing in firm that have high corporate value. Further research is suggested to analyze the fundamental influence on FV before and during the Covid-19 period. This cannot be done in this research because the data is still limited, considering that when this research was carried out, Covid-19 had just happened, and could use other sectors on the IDX to get a clearer picture regarding the factors that affect FV.

\section{REFERENCES}

Abbas, A., Naqvi, H. A., \& Mirza, H. H. (2013). Impact of large ownership on firm performance: A case of non financial listed companies of Pakistan. World Applied Sciences Journal, 21(8), 11411152. https://doi.org/10.5829/idosi.wasj.2013.21.8.1916

Arisadi, Y. C., Djumahir, \& Djazuli, A. (2013). Pengaruh Ukuran Perusahaan , Umur Perusahaan , Current Ratio , Debt to Equity Ratio dan Fixed Asset to Total Asset Ratio terhadap Kinerja Keuangan pada Perusahaan Manufaktur di Bursa Efek Indonesia. Jurnal Aplikasi Manajemen, (66), 567-574. Retrieved from https://jurnaljam.ub.ac.id/index.php/jam/article/view/593

Choi, H. M., Sul, W., \& Min, S. K. (2012). Foreign board membership and firm value in Korea. Management Decision, 50(2), 207-233. https://doi.org/10.1108/00251741211203533

Christiawan, Y. J., \& Tarigan, J. (2007). Kepemilikan Manajerial: Kebijakan Hutang, Kinerja Dan Nilai Perusahaan. Jurnal Akuntansi Dan Keuangan, 9(1), 1-8. https://doi.org/10.9744/jak.9.1.pp.1-8

CNBC. (2020). Diserap B30, Pengusaha Sawit Pede Tak Ekspor CPO Lagi. Retrieved from https://www.cnbcindonesia.com/news/20200113151226-4-129603/diserap-b30-pengusaha-sawitpede-tak-ekspor-cpo-lagi

Dahya, J., Dimitrov, O., \& McConnell, J. J. (2008). Dominant shareholders, corporate boards, and corporate value: A cross-country analysis. Journal of Financial Economics, 87(1), 73-100. https://doi.org/10.1016/j.jfineco.2006.10.005

Dewi, A. S. M., \& Wirajaya, A. (2013). Pengaruh Struktur Modal, Profitabilitas Dan Ukuran Perusahaan Pada Nilai Perusahaan. E-Jurnal Akuntansi, 4(2), 358-372. Retrieved from https://ojs.unud.ac.id/index.php/Akuntansi/article/view/6233

Driffield, N., Mahambare, V., \& Pal, S. (2007). How does ownership structure affect capital structure and firm value? Economics of Transition, 15(September 2005), 535-573. https://doi.org/10.1111/j.1468-0351.2007.00291.x

Gapki. (2020). Refleksi Industri Kelapa Sawit 2019 dan Prospek 2020. Retrieved from https://gapki.id/news/16190/refleksi-industri-kelapa-sawit-2019-dan-prospek-2020

Halim, H. A., \& Christiawan, Y. J. (2019). Pengaruh Penerapan Corporate Governance Terhadap Nilai Perusahaan Dengan Kinerja Keuangan Sebagai Variabel Mediasi. Business Accounting Review, $8(4)$, 181-192. Retrieved from http://publication.petra.ac.id/index.php/akuntansibisnis/article/view/6547

Haryati, W., \& Ayem, S. (2014). Pengaruh Return On Asset, Debt To Equity Ratio, dan Earning Per Share Terhadap Nilai Perusahaan. Jurnal Akuntansi, Vol.2 No.1(Juni 2014), 43-55. Retrieved from https://jurnalfe.ustjogja.ac.id/index.php/akuntansi/article/view/23

Hidayati, E. E. (2010). Analisis Pengaruh Der, Dpr, Roe Dan Size Terhadap Pbv Perusahaan 
Manufaktur Yang Listing Di Bei Periode 2005-2007. Jurnal Bisnis Strategi, 19(2), 166-174. https://doi.org//10.14710/jbs.19.2.166-174

Husaini, A. (2018). Pengaruh Net Profit Margin, Return On Equity, dan Earning Per Share terhadap Harga Saham. Jurnal Administrasi Bisnis, 45-47. Retrieved from https://profit.ub.ac.id/index.php/profit/article/view/132

Jensen, M. C., \& Meckling, W. H. (1976). Theory of the Firm: Managerial Behavior, Agency Costs and Ownership Structure. Journal of Financial Economics, 3, 305-360. https://doi.org/10.1016/0304-405X(76)90026-X

Kholis, N., Sumarmawati, D. E., \& Mutmainah, H. (2018). Faktor-Faktor yang Mempengaruhi Nilai Perusahaan. Jurnal Analisis Bisnis Ekonomi, 16(1), 19-25. https://doi.org/https://doi.org/10.31603/bisnisekonomi.v16i1.2127

Kusuma, P. A., \& Priantinah, D. (2012). Pengaruh Return on Investment (Roi), Earning Per Share (Eps), Dan Dividen Per Share (Dps) Terhadap Harga Saham Perusahaan Pertambangan Yang Terdaftar Di Bursa Efek Indonesia (Bei) Periode 2008-2010. Nominal, Barometer Riset Akuntansi Dan Manajemen, 1(2). https://doi.org/10.21831/nominal.v1i2.998

Lee, M., \& Choi, M. (2015). Analysis on Time-Lag Effect of Research and Development Investment in the Pharmaceutical Industry in Korea. Osong Public Health and Research Perspectives, 6(4), 241-248. https://doi.org/10.1016/j.phrp.2015.07.001

Lilianti, E. (2013). Struktur Aset Dan Earning Per Share Terhadap Nilai Perusahaan Sektor Pertambangan Di Bursa Efek Indonesia. Ilmu Manajemen, 3(1), 1. https://doi.org/10.32502/jimn.v3i1.243

Madison, K. J. (2014). Agency Theory and Stewardship Theory Integrated, Expanded, and Bounded by Context: An Empirical Investigation of Structure, Behavior, and Performance within Family Firms. University of Tennessee,Knoxville, 1-160. Retrieved from http://trace.tennessee.edu/utk_graddiss/2711

Maulana, F. (2014). Analisis Pengaruh Kinerja Keuangan Terhadap Harga Saham pada Perusahaan Makanan dan Minuman yang Terdaftar Di BEI Periode Tahun 2010-2012. Repository Universitas Jember, 2010-2015. Retrieved from http://repository.unej.ac.id/handle/123456789/63792

Myers, S. C. (1977). Determinants of Corporate Borrowing. Journal of Financial Economics, 5, 147175. https://doi.org/doi:10.1016/0304-405x(77)90015-0

Noviani, A. V., Atahau, A. D. R., \& Robiyanto, R. (2019). Struktur modal, profitabilitas, dan nilai perusahaan: Efek moderasi Good Corporate Governance. Jurnal Ekonomi Dan Bisnis, 22(2), 391-415. https://doi.org/10.24914/jeb.v22i2.2601

Pioh, H. T., Tommy, P., \& Sepang, J. L. (2018). Pengaruh Debt To Equity Ratio, Earning Per Share dan Return on Asset Terhadap Nilai Perusahaan Sub Sector Food and Beverages di Bursa Efek Indonesia. Jurnal EMBA: Jurnal Riset Ekonomi, Manajemen, Bisnis Dan Akuntansi, 6(4). https://doi.org/10.35794/emba.v6i4.21215

Putri, F. K., Rikumahu, B., \& Aminah, W. (2018). Kebijakan Hutang, Profitablitas, dan Manajemen Aset Terhadap Nilai Perusahaan. Jurnal Riset Akuntansi Kontemporer, 10(2), 80-89. Retrieved from http://journal.unpas.ac.id/index.php/jrak

Rachman, A. A., \& Maghviroh, R. El. (2012). Pengaruh Corporate Social Responsibility (Csr), Kepemilikan Manajerial Dan Institusional Terhadap Nilai Perusahaan. Jurnal Sekolah Tinggi Ilmu Ekonomi Perbanas, 114-119. Retrieved from https://eprints.perbanas.ac.id/3279/

Rahmantio, I., Saifi, M., \& Nurlaily, F. (2018). Pengaruh Debt to Equity Ratio , Return on Equity, Return on Asset dan Ukuran Perusahaan Terhadap Nilai Perusahaan ( Studi pada Perusahaan Pertambangan yang Terdaftar di Bursa Efek Indonesia Tahun 2012-2016). Jurnal Administrasi $\begin{array}{lllll}\text { Bisnis } & \text { (JAB), } & \text { 57(1), } & \text { Retrieved } & \text { from }\end{array}$ http://administrasibisnis.studentjournal.ub.ac.id/index.php/jab

Rinnaya, I. Y., Andini, R., \& Oemar, A. (2016). Pengaruh Profitabilitas, Rasio Aktivitas, Keputusan Pendanaan Keputusan Investasi Terhadap Nilai Perusahaan (Studi Empiris Pada Perusahaan Manufaktur Yang Terdaftar Di BEI Tahun 2010-2014). Jurnal Ilmiah Mahasiswa, 2(2). Retrieved from https://jurnal.unpand.ac.id/index.php/AKS/article/view/438

Rizqia, D. A., Aisjah, S., \& Sumiati. (2013). Effect of Managerial Ownership , Financial Leverage , 
Profitability, Firm Size, and Investment Opportunity on Dividend Policy and Firm Value. Journal of Finance and Accounting, 4(11), 120-130. Retrieved from http://www.iiste.org/journals/

Rustan, Said, D., \& Rura, Y. (2014). Pengaruh Struktur Kepemilikan terhadap Nilai Perusahaan: Kualitas Laba dan Kebijakan Hutang sebagai Variabel Intervening. Jurnal Analisis, 3(1), 32-39.

Sari, L. A., \& Hutagaol, Y. (2009). Debt to Equity Ratio, Degree of Operating Leverage Stock Beta and Stock Returns of Food and Beverages Companies on the Indonesian Stock Exchange. Binus Journal, 2(2), 368. Retrieved from https://journal.binus.ac.id/index.php/JAFA/article/view/149

SM, F., Safitri, E., \& Cholid, I. (2014). Pengaruh EPS, DPS, dan ROE Terhadap Nilai Perusahaan Property and Real Estate yang Terdaftar di Bursa Efek Indonesia. Ekonomi Manajemen, (x), 111. Retrieved from https://core.ac.uk/display/35319399

Subing, H. J. T., \& Susiani, R. (2019). Internal factors and firm value: A case study of Indonesia listed companies. Journal of Advanced Research in Dynamical and Control Systems, 11(3Special Issue), 412-416. https://doi.org/https://doi.org/10.26905/jkdp.v23i1.2405

Sujoko, \& Soebiantoro, U. (2017). Pengaruh Struktur Kepemilikan Saham, Leverage, Faktor Intern dan Faktor Ekstern Terhadap Nilai Perusahaan. EKUITAS (Jurnal Ekonomi Dan Keuangan), 11(2), 236. https://doi.org/10.24034/j25485024.y2007.v11.i2.2236

Suteja, J., \& Manihuruk, W. (2009). Pengaruh Struktur Modal , Kepemilikan, dan Faktor Eksternal pada Penentuan Nilai Perusahaan. Trikonomika, 8(2), 78-89. https://doi.org/10.13140/RG.2.2.12355.22565

Syamsuddin, L. (2007). Manajemen Keuangan Perusahaan: Konsep Aplikasi dalam Perencanaan, Pengawasan dan Pengambilan Keputusan. Jakarta: PT. Raja Grafindo Persada.

Untu, V., \& Welley, M. (2015). Faktor-Faktor Yang Mempengaruhi Nilai Perusahaan Di Sektor Pertanian Pada Bursa Efek Indonesia Tahun 2010-2013. Jurnal EMBA, 3(1), 972-983. Retrieved from https://ejournal.unsrat.ac.id/index.php/emba/article/view/7802

Warapsari, A. A. A. A. U., \& Suaryana, I. G. . A. (2016). Pengaruh Kepemilikan Manajerial Dan Institusional Terhadap Nilai Perusahaan Dengan Kebijakan Utang Sebagai Variabel Intervening. E-Jurnal Akuntansi, 16(3), 2288-2315. Retrieved from https://ojs.unud.ac.id/index.php/Akuntansi/article/view/20974

Wicaksana, A. W., Djailani, A. Q., \& BS., M. K. A. (2016). Analisis Pengaruh Return on Assets (ROA), Earning per Share (EPS), dan Debt to Equity Ratio (DER) Terhadap Nilai Perusahaan. E-Jurnal Riset Manajemen, 90-101. Retrieved from www.fe.unisma.ac.id

Widyastuti, T., \& Andamari, B. G. (2013). Faktor Fundamental, Suku Bunga dan Nilai Tukar Terhadap Return Saham. Jurnal Akuntansi Dan Auditing, 10(1), 13-28. https://doi.org/10.14710/jaa.10.1.13-28

Yumiasih, L., \& Isbanah, Y. (2017). Pengaruh Kompensasi, Ukuran Perusahaan, Usia Perusahaan, dan Leverage terhadap Nilai Perusahaan Sektor Pertanian yang Terdaftar di BEI Periode 2012-2015. Jurnal Ilmu Manajemen, 5(3), 1-9. Retrieved from https://journal.unesa.ac.id/index.php/jim/index 